\title{
El deber de negociar y el arbitraje potestativo como parte del contenido del derecho constitucional de negociación colectiva*
}

\section{Obligation of negotiation and facultative arbitration as part of constitutional law content on collective negotiation}

\author{
GUILLERMO BOZA PRÓ** \\ ERNESTO AGUINAGA MEZA***
}

Resumen: En este trabajo se estudian las bases constitucionales de dos instituciones centrales del derecho colectivo del trabajo: la obligación patronal de negociar colectivamente y el arbitraje potestativo. En lo que se refiere a la primera, utilizando las herramientas que proporciona la teoría del derecho, se sostiene que el artículo 28 de la Constitución consagra una concepción de la negociación colectiva como pretensión (y no como permiso), y por tanto, que es constitucional el deber legal de los empleadores de negociar colectivamente. En cuanto al segundo, se afirma que este encuentra sustento constitucional en la obligación estatal de promover formas pacíficas de solución de los conflictos laborales, aunque se cuestiona que la normativa infraconstitucional haya regulado esta institución de forma restrictiva.

Palabras clave: negociación colectiva - deber de negociar - pretensión permiso - arbitraje potestativo - buena fe - medios pacíficos de solución de controversias

Summary: This work studies constitutional bases of two essential institutions of Collective Labor Law: employer's obligation to negotiate collectively and facultative arbitration. In relation to the first one, using tools provided by the Theory of Law, it is argued that the section $28^{\circ}$ of Peruvian Constitution establishes a collective negotiation concept as claim (not as permission) so, employers legal obligation of collective negotiation is constitutional. In the other hand, regarding facultative arbitration, it has constitutional support on state's obligation to promote pacific ways to labor conflicts; even though, it is questioned that a «sub constitutional» rule has restrictively regulated this institution.

Key words: collective negotiation - duty to negotiate - claim - permission facultative arbitration - good faith - peaceful means to settle disputes

\footnotetext{
* Queremos agradecer los valiosos comentarios realizados al presente trabajo por los profesores Javier Neves, Wilfredo Sanguineti y Alfredo Villavicencio.

** Profesor y jefe del Departamento Académico de Derecho de la PUCP, abogado por la PUCP y doctor en Derecho por la Universidad de Sevilla. Correo electrónico: gboza@ pucp.edu.pe.

*** Profesor de la Facultad de Derecho de la PUCP, Lima-Perú, abogado por la PUCP y máster en Estudios Avanzados en Derechos Humanos por la Universidad Carlos III de Madrid. Correo electrónico: a19967049@pucp.edu.pe.
} 
CONTENIDO: I. INTRODUCCIÓN: CONSTITUCIONALIZACIÓN DE LOS DERECHOS LABORALES, ROL DE LA JUSTICIA CONSTITUCIONAL Y DERECHO DE NEGOCIACIÓN COLECTIVA.- II. EL DEBER DE NEGOCIAR COLECTIVAMENTE.- II.1.EL DEBER DEL EMPLEADOR DE NEGOCIAR COLECTIVAMENTE EN LA LEY DE RELACIONES COLECTIVAS DE TRABAJO: PLANTEAMIENTO DEL PROBLEMA.- II.2. LA NEGOCIACIÓN COLECTIVA EN LA CONSTITUCIÓN: EL DEBER DE FOMENTAR LA NEGOCIACIÓN COLECTIVA Y EL PRINCIPIO DE NEGOCIAR DE BUENA FE.- II.3 ¿DERECHO O LIBERTAD DE NEGOCIAR COLECTIVAMENTE?: LAS DIFERENCIAS TEÓRICAS ENTRE LAS NOCIONES JURÍDICAS DE PRETENSIÓN Y PERMISO.- II.4 EL PERMISO Y LA PRETENSIÓN CONSTITUCIONAL DE NEGOCIAR COLECTIVAMENTE.- III. NEGOCIACIÓN DE BUENA FE Y ARBITRAJE POTESTATIVO: ¿ARBITRAJE VOLUNTARIO O POTESTATIVO?

I. INTRODUCCIÓN: CONSTITUCIONALIZACIÓN DE LOS DERECHOS LABORALES, ROL DE LA JUSTICIA CONSTITUCIONAL Y DERECHO DE NEGOCIACIÓN COLECTIVA

La constitucionalización de los derechos laborales es, sin duda, uno de los hitos que permitió al derecho del trabajo su consolidación como una disciplina jurídica autónoma. Sus orígenes se ubican en la segunda década del siglo XX, en las constituciones de Querétaro de 1917 (México) y Weimar de 1919 (Alemania). No obstante, es recién después de finalizada la Segunda Guerra Mundial que este fenómeno empieza a asentarse, primero en Europa ${ }^{1}$ y luego en otros países, en particular de América Latina, donde la consagración de los derechos laborales al más alto nivel normativo cobra renovada fuerza a fines de la década de 1970 .

En el Perú, si bien encontramos antecedentes de la constitucionalización de los derechos laborales en las constituciones de 1920 y 1933, es recién con la Carta Fundamental de 1979 que un número significativo de estos derechos, tanto de naturaleza individual como colectiva, son recogidos en sede constitucional. Y es que con la Constitución de 1979 nuestro país se consagra como un Estado social y democrático de derecho, en el que se revalora el papel de la persona humana y del trabajo y los derechos económicos, sociales y culturales cobran inusitada importancia ${ }^{2}$.

Con la ruptura del orden constitucional por Alberto Fujimori, en abril de 1992, se acentuó el proceso de flexibilización del mercado de

1 Claros ejemplos de ello son la Ley Fundamental de la República Federal de Alemania de 1949 y las constituciones italiana de 1947, portuguesa de 1976 y española de 1978.

2 Como señala Landa, es en este marco constitucional donde «le correspondía al Estado promover las condiciones económicas y sociales para fomentar el empleo, crear igualdad de oportunidades, eliminar la pobreza y proteger al trabajador frente al desempleo y al subempleo». LANDA ARROYO, César. Prólogo al libro de Wilfredo Sanguineti Raymond, Derecho constitucional del trabajo. Relaciones de trabajo en la jurisprudencia del Tribunal Constitucional. Lima: Gaceta Jurídica, 2007, p. 5. 
trabajo y del ordenamiento laboral que había empezado a inicios de la década de 1990. La reforma, que fue calificada como lamás radical de América Latina, se dio en todos los niveles normativos y abarcó absolutamente todas las instituciones relevantes del derecho laboral y también de la seguridad social. Como nos recuerda Ermida ${ }^{3}$, la peruana fue tal vez «la experiencia más paradigmática de desregulación», debido a «la profundidad de las reformas, por tratarse de una imposición legislativa unilateral de desmejora, por incluir una re-regulación del derecho colectivo, e inclusive por consolidarse en el marco de una ruptura constitucional y de la disolución del Tribunal de Garantías Constitucionales».

La necesidad de la reforma se sustentó en la grave crisis económica y política generada durante en el primer gobierno de Alan García (19851990). Se calificaron de rígidas las normas laborales existentes y se planteó su eliminación porque, según el discurso neoliberal de la época -vigente hasta nuestros días - resultaban excesivamente protectoras y constituían una barrera para la creación de empleo. En este contexto, una posibilidad era la potenciación de la autonomía colectiva de los sujetos laborales, como una medida de resistencia o moderación, a través del diálogo y la negociación, del embate flexibilizador que venía produciéndose con fuerza en los derechos laborales individuales. No solo no se produjo una flexibilización negociada, sino que incluso la legislación de desarrollo de los derechos laborales colectivos (el decreto ley $25593^{4}$ ) resultó restrictiva e intervencionista, terminando de consolidar un modelo descentralizado de relaciones colectivas de trabajo que afectó decididamente al movimiento sindical y los niveles de protección de los derechos de los trabajadores en nuestro país ${ }^{5}$. La intención era clara, y no hubo pudor en señalarlo expresamente por el ministro de Economía de entonces:

[...] el objetivo de la reforma en el mercado laboral es su flexibilización, tanto a nivel de la libre entrada o salida de este (libertad para reducir y aumentar el personal), como de libre determinación de los salarios y la reducción de los costes laborales. Se requiere acabar con el poder

3 ERmida URIARTE, Óscar. «La flexibilidad». En Autores varios, Estudios sobre la flexibilidad en el Perú. Documento de Trabajo 124. Lima: Oficina Internacional del Trabajo, 2000, p. 17.

4 Actualmente Texto Único Ordenado del decreto ley 25593, Ley de Relaciones Colectivas de Trabajo, aprobado por el decreto supremo 010-2003-TR (en adelante, LRCT).

5 Vale la pena recordar algunas cifras a inicios del año 2000 , luego de la reforma de la década anterior: (i) la tasa de desempleo en el país no varió significativamente (en 1990 no superaba el 7\%); (ii) la tasa del empleo informal creció de $50 \%$ a cerca del $70 \%$; (iii) el número de contratos de trabajo a plazo indeterminado en el sector privado se redujo de cerca del $50 \%$, en la década anterior, al $25 \%$, y el número de contratos a plazo fijo, que no superaba el $30 \%$, subió a casi $75 \%$; (iv) la afiliación sindical en la capital se pulverizó, cayó del $22 \%$ al $2,8 \%$ y en el paísdel $14 \%$ a menos del $7 \%$; (v) el número de convenios colectivos celebrados cayó a la cuarta parte, aproximadamente a quinientos en el año; (vi) el número de huelgas en el paíscayó de setecientosa menos de cienpor año. En Álvaro VIDAL Bermúdez, Fernando CuAdRos LuQue y Christian SÁnCHEZ ReYES. Flexibilización laboral en el Perú y reformas de la protección social asociadas: un balance tras veinte años. Santiago: CEPAL, 2012, p. 9. 
monopólico de los sindicatos en las negociaciones de las condiciones de trabajo y en el uso de la huelga como mecanismo de negociación ${ }^{6}$.

Lo anterior supuso un ataque directo a los derechos de libertad sindical y un desprecio explícito a la impronta que ha tenido el principio de la autonomía colectiva en la construcción del derecho del trabajo, y por supuesto, también al rol que la Constitución violentada de 1979 - e incluso la de 1993 - reconocieron a dicho principio como eje articulador del sistema de relaciones laborales y como medio a través del cual los sujetos laborales buscan regular directamente sus intereses en conflicto. $\mathrm{Y}$ es que el reconocimiento de las manifestaciones centrales del principio de la autonomía colectiva (sindicación, negociación colectiva y huelga) ha ido evolucionando de la mano de la consolidación del derecho al trabajo. Así, su naturaleza jurídica ha conocido diferentes consideraciones hasta arribara su reconocimiento como derechos, una vez superadas las fases de delito y libertad. Incluso en su estadio como derechos han pasado del reconocimiento legal al constitucional, hasta su consagración actual como derechos humanos.

La Constitución vigente de 1993 fue concebida como una norma ad hoc para adecuar y convalidar al más alto nivel todos los cambios que se habían producido en el modelo político y económico (también en el laboral) en los años previos, y que continuaron y se vieron facilitados luego de la entrada en vigor del nuevo texto constitucional. Con todo, no deja de llamar la atención el reconocimiento que la Constitución hace de los derechos laborales de naturaleza colectiva. ¿Concesión o logro? ${ }^{7}$ iO tal vez compensación por el adelgazamiento sufrido —en cantidad y calidad - por los derechos laborales individuales en el propio texto constitucional? No obstante, no puede dejar de señalarse que en la práctica, y en el plano de la normativa infraconstitucional, se mantuvo un marcado carácter restrictivo y reglamentarista del sistema de relaciones colectivas de trabajo.

Como fuere, no es sino hasta la vuelta a la normalidad democrática, a fines del año 2000, que empezó a estrecharse el desfase existente entre lo consagrado en la Constitución y lo regulado en su normativa

6 BoloñA, Carlos. Cambio de rumbo: el programa económico para los 90. Lima: Instituto de Economía de Libre Mercado, p. 76.

7 SANGUINETI, luego de preguntarse si el «bloque de laboralidad» en la Constitución vigente constituye una concesión $\mathrm{o}$ un freno al neoliberalismo, concluye que, pese a la significativa reducción del volumen de derechos laborales y a su intensidad tutelar en la Constitución de 1993, «las señas de identidad del modelo de relaciones laborales consagrado por esta última no se han visto alteradas en lo sustancial». Agrega el citado autor que «[...] el derecho del trabajo como estructura institucional orientada a ofrecer una regulación equilibrada de las relaciones de trabajo mediante la actuación combinada de la intervención protectora del Estado y la libre actuación de los sujetos colectivos en defensa de sus intereses es perfectamente reconocible dentro del texto constitucional, encontrándose sus principales instrumentos e instituciones garantizados al máximo nivel normativo". SANGUINETI RAYMOND, Wilfredo. Derecho constitucional del trabajo. Relaciones de trabajo en la jurisprudencia del Tribunal Constitucional. Lima: Gaceta Jurídica, 2007, pp. 21-23, 30-31. 
de desarrollo, a partir de un decidido papel del reconstituido Tribunal Constitucional, que empieza a apuntalar la idea de un Estado constitucional de derecho, donde la primacía de la Constitución y el respeto de los derechos que esta reconoce a las personas resultan indiscutibles. Y en esta tarea, prácticamente no existe hoy disciplina jurídica que no haya sido impregnada por el derecho constitucional, lo que ha ocurrido, por supuesto, también con los derechos laborales.

Precisamente ha sido en el ejercicio de su competencia de control constitucional que la jurisprudencia del Alto Tribunal «ha ido delimitando y/o expulsando las normas y prácticas laborales contrarias o no conformes con el modelo constitucional normativo y viviente - living constitution— ${ }^{8}$, pero al mismo tiempo, frente a los vacíos o deficiencias de la normativa infraconstitucional, ha ido configurando, «[...] bajo los parámetros de la interpretación constitucional y sus técnicas de razonabilidad y proporcionalidad, los derechos de carácter individual y colectivo, así como los principios constitucionales laborales [...]»⿳ .

En lo que toca al presente trabajo, nos interesa estudiar en clave constitucional dos aspectos centrales del derecho de negociación colectiva. Por un lado, analizaremos la esencia misma del derecho de negociación colectiva con el fin de determinar si nos encontramos ante un derecho propiamente dicho reconocido a los trabajadores, con la correlativa obligación de negociar de la contraparte empresarial, o si estamos simplemente ante una libertad de negociar, lo que supondría colocar a la negociación colectiva en la esfera de la absoluta voluntariedad (negociación libre y voluntaria). En segundo lugar, queremos establecer si el arbitraje, como uno de los medios alternativos de solución de conflictos recogidos en sede constitucional ante el fracaso de la negociación directa entre los representantes de los trabajadores y del empleador, es voluntario o potestativo.

Lo anterior nos exige realizar un análisis de la jurisprudencia constitucional, de cara a conocer cómo se ha ido decantando la configuración de estas instituciones en el Alto Tribunal. Aunque hay que advertir de entrada, como lo adelantara años atrás otro autor, que la jurisprudencia del Tribunal Constitucional en esta materia

8 En ocasiones, incluso, ese modelo constitucional se ha ido moldeando a partir del reconocimiento implícito que pueda encontrase o derivarse de un derecho fundamental de carácter general. ZACHERT, comparando el ordenamiento constitucional alemán con el español, ha señalado: «Es cierto que en nuestra Ley Fundamental del año 1949 no se encuentran regulados expresamente tantos derechos fundamentales del trabajador como en la Constitución española de 1978. La principal disposición, en ese sentido, se trata de la garantía de la libertad de coalición, y es el artículo 9, párr. 3, de la Ley Fundamental. Pero cabe mencionar que, además, nuestra Corte Constitucional ha deducido a partir de los derechos fundamentales generales, una serie de derechos específicos individuales del trabajador». ZACHERT, Ulrich. «La estructura de las relaciones laborales en Alemania». Anuario da Facultade de Dereito da Coruña, 11 (2007), p. 1029.

9 L. cit.

EL DEBER DE NEGOCIAR Y

EL ARBITRAJE POTESTATIVO COMO PARTE DEL CONTENIDO DEL DERECHO CONSTITUCIONAL DE NEGOCIACIÓN COLECTIVA

OBLIGATION OF NEGOTIATION AND FACULTATIVE ARBITRATION AS PART OF CONSTITUTIONAL LAW CONTENT on COLlective NEGOTIATION 
es poco abundante ${ }^{10}$, a lo que habría que agregar que, en algunos extremos, resulta incluso contradictoria ${ }^{11}$.

La Constitución vigente reconoce en su artículo 28, junto a los derechos de sindicación y huelga, el derecho de negociación colectiva. En efecto, señala expresamente el indicado precepto que el Estado reconoce el derecho a la negociación colectiva, y agrega en el inciso 2 :

2. Fomenta la negociación colectiva y promueve formas de solución pacífica de los conflictos laborales.

La convención colectiva tiene fuerza vinculante en el ámbito de lo concertado. [...].

Como se aprecia, el derecho de negociación colectiva ha recibido un tratamiento bastante completo. Hay una referencia expresa a tres instituciones medulares del derecho en cuestión: a la negociación colectiva propiamente dicha, al convenio colectivo de trabajo como producto por excelencia de la negociación, y finalmente, a los medios alternativos de solución de controversias ante el fracaso de la negociación y la imposibilidad de las partes de llegar a un acuerdo directo. Por otro lado, las expresiones «fomento» (de la negociación colectiva) y «promoción» (de formas de solución de conflictos laborales) nos indican que no estamos ante un reconocimiento cualquiera, sobre todo si lo comparamos con la opción garantista a la que aludía la Constitución de 1979. Y si bien sobre esto volveremos más adelante, creemos que no se trata de un simple cambio semántico.

Parece claro que para el constituyente no era suficiente el simple reconocimiento de las instituciones en cuestión, de ahí que haya precisado la necesidad de su fomento en un caso, y de su promoción en el otro, lo que dota de una especial consideración al derecho de negociación colectiva y a los medios alternativos de solución de conflictos. Esta forma de reconocimiento se explica, además, en el marco del Estado social y democrático de derecho, donde la autonomía colectiva «se configura como un mecanismo corrector de la autonomía

10 Cf. SANGUINETI RAYMOND, Wilfredo. Ob. cit., p. 58.

11 Al respecto, señala Landa (Ob. cit.2007, p. 6) que «el Tribunal Constitucional ha tenido oportunidad de pronunciarse sobre la naturaleza sustantiva y procesal de los derechos constitucionales de naturaleza laboral; sin embargo, este no ha sido un tema que el tribunal haya emprendido siempre con claridad en sus primeras sentencias, durante su etapa de cautiverio al régimen fujimorista, sino recién a partir de la caída de este, cuando se restablece el régimen democrático de respeto de los derechos y libertades civiles, políticos y sociales». Coincidimos con el autor en que, con la vuelta a la normalidad democrática, el Tribunal Constitucional ha jugado un rol trascendental en el fortalecimiento del Estado de derecho y el respeto de los derechos consagrados en la Constitución. No obstante, en esta etapa también hemos conocido sentencias del TC que no destacan precisamente por su claridad, resultan confusas y en ocasiones parecen marcar un retroceso respecto del avance alcanzado en la protección de los derechos laborales. El caso de la protección frente al despido arbitrario de los trabajadores de confianza o del contrato administrativo de servicios pueden citarse como ejemplos de la situación antes descrita. 
individual» ${ }^{12}$ y 13 , es decir, se corresponde con la verdadera naturaleza de la negociación colectiva, cuya función institucional reside en la búsqueda del reequilibrio de relaciones esencialmente desiguales o asimétricas como las del contrato individual de trabajo ${ }^{14}$.

Estapercepción cobrasentidoal considerar las diversasincompatibilidades existentes entre la LRCT y la norma constitucional. Como ha recordado Sanguineti ${ }^{15}$, desde un principio «la doctrina se encargó de destacar el mayor compromiso que la inclusión de [este] deber suponía para el Estado, así como su difícil compatibilidad con varias de las disposiciones contenidas en la Ley de Relaciones Colectivas de Trabajo, cuya formulación parecía responder más a un propósito de dificultar el ejercicio de este derecho o restarle efectividad que de incentivarlo» ${ }^{16}$.

\section{EL DEBER DE NEGOCIAR COLECTIVAMENTE}

\section{II.1. El deber del empleador de negociar colectivamente en la Ley de Relaciones Colectivas de Trabajo: plan- teamiento del problema}

De conformidad con la LRCT, en el Perú los empleadores están obligados a negociar colectivamente con sus trabajadores. Pero, iqué comprende exactamente este deber de negociar? En nuestro concepto, este deber supone dos cosas: en primer lugar, el nivel en el que se negocia, y en un segundo momento — decidido lo anterior-, el contenido del posible acuerdo colectivo. Lo lógico es que la determinación del nivel se dé en la primera oportunidad en que es emplazada la parte empresarial por el colectivo de trabajadores correspondiente. Pero esta no es una decisión pétrea, inamovible en el tiempo, pues en cada nueva negociación resulta perfectamente posible que se discuta el cambio del nivel de negociación. Según las disposiciones vigentes, si en la primera negociación las partes

12 Blancas Bustamante, Carlos. La cláusula de Estado social en la Constitución: análisis de los derechos fundamentales laborales. Lima: Fondo Editorial PUCP, 2011, p. 436.

13 Sala Franco, Tomás e Ignacio Albiol Montesinos. Derecho sindical. Valencia: Tirant lo Blanch, 2003, p. 30.

14 Para SALA Y ALBIOL (2003, p. 30), en una democracia social, la exigencia de justicia social puede alcanzarse mediante la atribución constitucional de poderes a la colectividad de trabajadores, en tanto destinatarios de dicha exigencia, «siendo, concretamente, la negociación colectiva, los medios de solución extrajudicial de los conflictos laborales y la huelga los instrumentos de realización de aquella justicia social».

15 SANGUINETI RAYMOND, Wilfredo. Ob. cit.

16 En una interpretación sistemática del artículo 28 de la Constitución y la normativa internacional, podemos llegar a resultados similares. Señala al respecto Villavicencio que la negociación colectiva en sede internacional «no solo es reconocida como un derecho sino como una viga maestra del ordenamiento internacional, en la medida en que es el canal principal de expresión de la libertad sindical, la que es fundamento ideológico de la propia OIT». Por tal razón, para el referido autor, «las referencias a la negociación colectiva no son referencias neutras sino que suponen la obligación de promover la negociación colectiva, de fomentarla, porque se entiende que es el instrumento más apropiado para canalizar los conflictos inherentes a la relación laboral y darle una solución idónea y de consenso" (2007, p. 67). 
no se ponen de acuerdo en el nivel, el tema se resuelve en arbitraje; por el contrario, en la segunda y siguientes negociaciones para que ocurra el cambio de nivel será necesario el acuerdo de partes, y de no haberlo se continúa negociando en el mismo nivel.

En consecuencia, la LRCT claramente dispone que, antes de pasar a discutir las peticiones presentadas por las organizaciones de trabajadores, debe fijarse de común acuerdo el ámbito en el que se desarrollará la negociación ${ }^{17}$. En tal sentido, cualquiera sea el nivel en el que se pretenda negociar, si una organización sindical presenta un pliego de reclamos a ser negociado en determinado nivel, de conformidad con la LRCT, el empleador uorganización patronal del sector respectivo tendrá la obligación de sentarse a negociar esta primera cuestión. Esta suerte de negociación preliminar — como el resto de la negociación- está sujeta a las exigencias provenientes del principio de buena $\mathrm{fe}^{18}$. Una vez fijado el nivel de negociación,la norma mencionada establece la obligación del empleador de recibir el pliego de reclamos presentado por el sindicato correspondiente $^{19} \mathrm{y}$, sobre todo, de sentarse a negociar el contenido del mismo en un plazo máximo de diez días ${ }^{20}$.

Vistas de esa manera las reglas de la LRCT, es lógico afirmar que, para la parte patronal de la relación laboral — siempre que tengan al menos un año de existencia ${ }^{21}$ _ no es libre o voluntaria la decisión de iniciar la negociación colectiva. Y es que, en tanto dicho dispositivo les fija el deber de negociar, no tendrán legalmente la posibilidad de rechazar la pretensión de los trabajadores (o de sus organizaciones representativas) de negociar colectivamente (ya sea el pliego, ya sea el nivel). Vale decir, según lo establecido por la LRCT, siempre que la parte laboral plantee el inicio de los procedimientos de negociación colectiva, la parte empresarial quedará vinculada por estay, como tal, estará legalmente coaccionada a sentarse en la mesa de negociación. No tiene, pues, libertad para decidir si acude o no a aquella ${ }^{22}$.

Ahora bien, la opción legislativa por un régimen obligatorio de negociación colectiva (para los empleadores), a primera vista, no parece encajar con lo previsto en el Convenio 98 de la OIT, sobre el derecho

17 Cf. artículo 45 de la LRCT.

18 En nuestra opinión el segundo párr. del artículo 54 de la LRCT no es aplicable solo a la negociación del pliego sino también a la negociación del nivel. En todo caso, que el principio de buena fe es aplicable en este primer momento queda claro con la sentencia del Tribunal Constitucional recaída en el caso de los trabajadores portuarios, tal como veremos más adelante.

19 Cf. artículos 53 y 54, primer párr., de la LRCT.

20 Cf. artículo 57 de la LRCT.

21 Cf. artículo 41 de la LRCT.

22 Como explica Villavicencio: «el deber de negociar consiste, fundamentalmente, en una limitación de la libertad de negociación, una compulsión a una obligación de hacer, en el sentido de obligar a que las partes se sienten en la mesa de negociación». VILLAVICENCIO Ríos, Alfredo. Los acuerdos marco sobre la estructura de la negociación colectiva: naturaleza jurídica, eficacia, contenido. Granada: Comares, 1998, pp. 409-410. 
de sindicación y de negociación colectiva ${ }^{23}$. En efecto, dicho tratado establece literalmente la obligación estatal de adoptar medidas dirigidas a estimular y fomentar «el pleno desarrollo y uso de procedimientos de negociación voluntaria, con objeto de reglamentar, por medio de contratos colectivos, las condiciones de empleo» ${ }^{24}$.

El propio Comité de Libertad Sindical de la OIT ha señalado que el principio de negociación libre y voluntaria supone que «la negociación voluntaria de convenios colectivos - - , por tanto, la autonomía de los interlocutores sociales en la negociación - constituye un aspecto fundamental de los principios de la libertad sindical $»^{25} \mathrm{y}$, en esa medida, que «la negociación colectiva, para ser eficaz, debe tener carácter voluntario y no implica el recurso a medidas de coacción que alterarían el carácter voluntario de dicha negociación ${ }^{26}$. Ello es así porque, para dicho Comité, «ninguna disposición del artículo 4 del Convenio 98 obliga a un gobierno a imponer coercitivamente un sistema de negociaciones colectivas a una organización determinada, intervención gubernamental que claramente alteraría el carácter de tales negociaciones» ${ }^{27}$.

Todo parece indicar, entonces, que la obligación patronal de negociar colectivamente no viene exigida o impuesta por la OIT ${ }^{28}$ pero $-\mathrm{y}$ es conveniente resaltar esto- tampoco la proscribe. Efectivamente, aun cuando el mencionado Comité reconoce que «el artículo 4 del Convenio 98 no impone de manera alguna al gobierno el deber de negociar colectivamente», también señala que «tampoco resulta contrario a dicho artículo el obligar a los interlocutores sociales a entablar negociaciones sobre términos y condiciones de trabajo con miras a estimular y fomentar el desarrollo y la utilización de los mecanismos de la negociación colectiva de las condiciones de trabajo ${ }^{29}$. En ese sentido, de acuerdo con el Comité de Libertad Sindical, los instrumentos internacionales señalados dejan al derecho interno la decisión de establecer (o no) un sistema obligatorio de negociación colectiva, de forma que será compatible con el Convenio 98 tanto si se prevé como si no el deber de negociar colectivamente. Y si ello es así, entonces, corresponde evaluar

23 Ratificado por el Perú el 13 de marzo de 1964 y, como tal, forma parte integrante de nuestro derecho interno (artículo 55 de la Constitución), y del bloque de constitucionalidad del artículo 28.2 de la Constitución, conforme a lo señalado en la sentencia del TC del 17 de agosto de 2009, recaída en el expediente 035561-PA/TC.

24 Artículo 4 del Convenio 98 de la OIT (la cursiva es nuestra).

25 OIT. Libertad sindical: recopilación de decisiones y principios del Comité de Libertad Sindical del Consejo de Administración de la OIT. Quinta edición revisada. Ginebra: Oficina Internacional del Trabajo, 2006, p. 925.

26 La cursiva es nuestra. Ibíd., párr. 926.

27 lbíd., párr. 927.

28 Mucho más claro, incluso, resulta ser el Convenio 154 de la OIT, sobre la negociación colectiva, que en su artículo 8 textualmente dirá que las medidas que se establezcan con el fin de fomentar la negociación colectiva «no deberán ser concebidas o aplicadas de modo que obstaculicen la libertad de negociación colectiva» (este instrumento internacional no ha sido ratificado por el Estado peruano).

29 lbíd., párr. 928.

EL DEBER DE NEGOCIAR Y

EL ARBITRAJE POTESTATIVO COMO PARTE DEL CONTENIDO DEL DERECHO CONSTITUCIONAL DE NEGOCIACIÓN COLECTIVA

OBLIGATION OF NEGOTIATION AND FACULTATIVE ARBITRATION AS PART OF CONSTITUTIONAL LAW CONTENT on COLLECTIVE NEGOTIATION 
si existen bases constitucionales sólidas que sustenten la opción por la negociación colectiva obligatoria prevista en la LRCT (o, al menos, que no la proscriban). A continuación nos dedicaremos a esclarecer esto.

\section{II.2. La negociación colectiva en la Constitución: el deber de fomentar la negociación colectiva y el principio de negociar de buena fe}

Pues bien, itiene base constitucional el deber de los empleadores de negociar colectivamente? Villavicencio ha sostenido que dicha obligación patronal se sostiene, porun lado, en la obligación estatal de fomentar y promover la negociación colectiva y, de otro, en el principio de negociar de buena $\mathrm{fe}^{30}$. Así, en un primer momento, afirmó que «el deber de negociar (no de convenir) implica el rompimiento con la concepción clásica de la negociación colectiva como un mero derecho de libertad del cual no podía extraerse ninguna posibilidad de coaccionar a cualquiera de las partes - la empresarial generalmente- a negociar con la otra, marcando un necesario abstencionismo estatal en ese sentido. Se arropa en una concepción moderna de los derechos fundamentales y en la necesidad de promover la negociación colectiva que explícitamente se prevé en los instrumentos internacionales, según las cuales no basta con eliminar todos los obstáculos para que pueda materializarse (protección negativa) sino que importa una actividad normativa estatal concreta dirigida a garantizar su efectividad (protección positiva)» ${ }^{31}$.

Es decir, para este autor, si no se entiende mal, la obligación de los empleadores de sentarse a negociar se sostiene en la consideración de la negociación colectiva como derecho fundamental (que lo es) y en el deber de promoverla: ambos factores modificarían su carácter (se rompería con la concepción clásica de derecho-libertad) y, como tal, la actitud del Estado frente a ella, que, de ser puramente abstencionista, pasa a asegurar su eficacia real por medio de la emisión de acciones normativas. Entre estas medidas legislativas se encontraría el deber legal de negociar colectivamente.

En un segundo momento, el citado autor señala que el principio de negociar de buena fe es, en realidad, el apoyo constitucional del deber empresarial de negociar colectivamente. En sus palabras, «el derecho de negociación colectiva exige, en primer lugar, que esta sea realizada de buena fe, y este principio de negociar de buena fe es fundamental en el ámbito de la OIT porque supone la obligación de reconocer al interlocutor sindical cuando este es auténtico y representativo,

30 La constitucionalidad del mencionado principio ha quedado claramente establecido en la sentencia del Tribunal Constitucional del 17 de agosto de 2009, recaída en el expediente 03561-2009-PA/TC, párr. 16-17.

31 VillaVicencio Ríos, Alfredo. Los acuerdos marco... Ob. cit., pp. 410-411. 
no pudiendo la contraparte negarse a negociar con una organización sindical que lo sea ${ }^{32}$.

Es por ello que, aun cuando reconoce que «la negociación colectiva debe ser llevada a la práctica por los sujetos colectivos sin imposición por parte del Estado», también afirma que «el grado de voluntariedad debe matizarse a la luz de los condicionantes derivados de la buena fe en la negociación colectiva que indican que los empleadores deban entablar negociaciones con las organizaciones sindicales representativas. Así, la propia Recomendación 163 dispone que deberá adoptarse las medidas adecuadas para que las organizaciones representativas de empleadores y de trabajadores sean reconocidas a los efectos de la negociación colectiva (punto 3.a)» ${ }^{33}$.

En este orden de ideas, el principio de negociar de buena fe, en tanto exige que el empleador reconozca al interlocutor sindical, supone a su vez un límite al principio de negociación libre y voluntaria: la parte patronal ya no podrá negarse a negociar (iqué otro objeto tendría el obligar a reconocer a la parte sindical sino es, precisamente, para que se dé inicio al trato directo? $)^{34}$.

Sin negar la seriedad de estos planteamientos, en nuestra opinión, tanto el deber de fomentar y promover la negociación colectiva como el principio de negociación de buena fe, por sí solos, no son suficientes para apuntalar el deber patronal de negociar colectivamente con los trabajadores.

Efectivamente, en lo que se refiere al primero, se ha afirmado que su presencia cambia el carácter de derecho-libertad de la negociación colectiva: ya no se exigirían solo abstenciones sino también acciones, lo quepermitiría al Estado imponer la obligación de negociar a la parte patronal. Pues bien, aun cuando es cierto que el deber de fomentar y promover la negociación colectiva, en tanto derecho fundamental, exige del Estado una actitud positiva en su defensa ${ }^{35}$, también lo es que ello no supone necesariamente la transformación del carácter

32 VILLAVICENCIO Ríos, Alfredo. La libertad sindical en las normas y pronunciamientos de la OIT: sindicación, negociación colectiva y huelga. Montevideo: Fundación de Cultura Universitaria, 2007, p. 68.

33 Ibíd., pp. 68-69.

34 En un trabajo reciente, Villavicencio desarrolla esta idea, señalando que: «[...] el derecho de negociación colectiva exige que esta sea realizada de buena fe, lo que implica que las partes deben desarrollar las negociaciones de manera verdaderamente constructiva con la finalidad de arribar a un convenio colectivo y que una parte no puede negarse a negociar con la otra, nombrar representantes sin capacidad de obligarla, dilatar la negociación indebidamente, no entregar la información económica requerida y pertinente, entre otras medidas". VILLAVICENCIO Ríos, Alfredo. "Artículo 28: Derechos de sindicación, negociación colectiva y huelga». En Walter GUTIÉRREZ (dir.). La Constitución comentada: análisis artículo por artículo. Segunda edición. Lima: Gaceta jurídica, 2013, Tomo I, p. 770.

35 Blancas ha sostenido que, en virtud de dicho deber, «resulta que nuestra Constitución, en materia de negociación colectiva, supera una concepción meramente garantista del derecho, para asumir [...] un rol activo destinado a asegurar su plena efectividad» (BLANCAS, Carlos. Ob. cit., p. 446).

\section{EL DEBER DE NEGOCIAR Y \\ EL ARBITRAJE POTESTATIVO COMO PARTE DEL CONTENIDO DEL DERECHO CONSTITUCIONAL DE NEGOCIACIÓN COLECTIVA}

OBLIGATION OF NEGOTIATION AND FACULTATIVE ARBITRATION AS PART OF CONSTITUTIONAL LAW CONTENT on COLLECTIVE NEGOTIATION 
de derecho-libertad de la misma. Y no lo hace porque, precisamente una concepción moderna de los derechos fundamentales, sostiene: (i) que las normas jurídicas que los recogen, por su contenido o las expectativas que incorporan, pueden ser «libertades» en todo el sentido del término ${ }^{36}$, y sobre todo (ii) que estas últimas también requieren para verse plenamente satisfechas de un cúmulo de obligaciones positivas que van más allá del simple abstencionismo estatal, tal como el deber de evitar, por medio de la dación de medidas legislativas (una protección positiva), que otros privados impidan al titular de la libertad decidir realmente si realiza o no lo que el ordenamiento le permite hacer ${ }^{37}$.

En tal sentido, señalar que la negociación colectiva tiene la condición de derecho fundamental que debe ser fomentado o promovido no supone rechazar automáticamente su posible carácter de derecho-libertad y, de esta forma, que el deber de fomento y promoción simplemente exige del Estado la emisión de todas las normas jurídicas que sean necesarias para asegurar que las partes puedan decidir, sin interferencias de terceros (públicos o privados), si acuden o no a la negociación colectiva. $\mathrm{Ni}$ la presencia de deberes positivos, ni su inclusión en los catálogos de derechos fundamentales, por tanto, son los factores que cambian el carácter de «libertad» de la negociación colectiva.

En ese sentido, para afirmar que el deber estatal de fomentar y promover la negociación colectiva supone la obligación patronal de negociar colectivamente, es necesario primero sostener que la negociación colectiva no es una libertad sino un derecho en todo el sentido de la palabra (como veremos a continuación). No es, pues, que el deber de fomentar y promover cambia el carácter de la negociación colectiva, sino que el sentido de esta última condiciona el contenido de aquel.

¿Y en lo referido al principio de buena fe? ¿Puede ser el sustento constitucional del deber que la LRCT le impone a la patronal de negociar colectivamente? De acuerdo con el Comité de Libertad Sindical de la OIT, en virtud de este principio, «tanto los empleadores como los sindicatos deben negociar [...] realizando esfuerzos para llegar a un acuerdo» ${ }^{38}$, es decir, exige que las partes «hagan todo lo posible por llegar a un acuerdo» razón por la cual debe evitarse «todo retraso injustificado en el desarrollo de las negociaciones» ${ }^{39}$ y, sobre todo,

36 FerRajol, Luigi. Principia iuris: teoría del derecho y de la democracia. En Perfecto Andrés IBÁÑEZ, Carlos BAYón, Marina GASCÓn, Luis PRIETO SANCHís y Alfonso Ruiz Miguel (trads.). Madrid: Trotta, 2011, Vol. I, pp. 701-717.

37 ALEXY, Robert. Teoría de los derechos fundamentales. Madrid: Centro de Estudios Constitucionales, 1997, pp. 224-227.

38 OIT. Libertad sindical: recopilación de decisiones y principios del Comité de Libertad Sindical del Consejo de Administración de la OIT. Quinta edición revisada. Ginebra: Oficina Internacional del Trabajo, 2006. párr. 936.

39 lbíd., párr. 935 y 937. 
respetarse y cumplirse los consensos que se hubieran alcanzado ${ }^{40}$. Según esta definición, parece ser que este principio empieza a operar después de haberse dado inicio a la negociación colectiva y, por ende, no sería aplicable en la etapa previa o, lo que es lo mismo, en el momento en el que las partes deciden acudir a esta (que es cuando regiría el deber de negociar). Dicho de otra manera, no parece ser que suponga un límite a la libertad de negociar tanto de trabajadores como de empleadores.

Es por ello que coincidimos con Elías cuando afirma que «bien podría decirse que la obligación de negociar constituye un deber distinto de la obligación de negociar de buena fe», de forma que no sería incoherente un régimen en el que «los sujetos no pueden ser constreñidos a negociar, pero si deciden asumir la negociación, quedarán obligados a obrar de buena fe» ${ }^{41}$. En ese sentido, aun cuando se sostenga que conforme al principio de buena fe el empleador está obligado a reconocer a la representación designada por la parte laboral, también habrá que aceptar que ello no supone necesariamente que aquel, desde el inicio, tenía la obligación de negociar con esta.

$\mathrm{Y}$ es que, en tanto la buena fe operaría en una etapa posterior, bien podría alegarse que una vez que las partes voluntariamente han aceptado negociar, estas recién estarían obligadas a reconocer a los representantes designados a fin de dar inicio efectivamente al trato directo. Desde nuestro punto de vista, por lo tanto, al igual que en el caso del deber de fomento y promoción, el deber de negociar de buena fe por sí solo no parece ser suficiente para justificar la existencia del deber patronal de negociar.

\section{II.3. ¿Derecho o libertad de negociar colectivamente?: las diferencias teóricas entre las nociones jurídicas de pretensión y permiso}

Como se puede apreciar, ni el deber estatal de fomentar y promover la negociación ni el deber de las partes de negociar de buena fe supone o da cobertura necesariamente al deber legal de negociar. A nuestro juicio, la única base o sustento posible de este último reside en considerar a la negociación colectiva como un derecho en sentido estricto.

En efecto, desde que la LRCT fija el deber de negociar de los empleadores, es lógico afirmar que esta, a su vez, presupone que los trabajadores (o sus organizaciones representativas) tienen el derecho de negociar colectivamente con aquellos ${ }^{42}$. Ello es así porque, tal como (coord.). Tratado de derecho del trabajo. Santa Fe/Buenos Aires: Rubinzal-Culzoni Editores, 2007, Tomo VIII, pp. 243-244.

42 Como bien señala Blancas, citando a Alonso Olea, «si existe el derecho a la negociación es porque existe el deber de negociar» (Ibíd., 2011, p. 444).

EL DEBER DE NEGOCIAR Y

EL ARBITRAJE POTESTATIVO COMO PARTE DEL CONTENIDO DEL DERECHO CONSTITUCIONAL DE NEGOCIACIÓN COLECTIVA

OBLIGATION OF NEGOTIATION AND FACULTATIVE ARBITRATION AS PART OF CONSTITUTIONAL LAW CONTENT on COLLECTIVE NEGOTIATION 
nos recuerda Hohfeld, los términos derecho y deber son correlativos jurídicamente hablando. Vale decir, cuando el ordenamiento jurídico reconoce el primero automáticamente establece el segundo y viceversa: si le impone a alguien la obligación de hacer o no hacer algo, es porque a alguien previamente le ha otorgado el derecho de que se haga o no se haga ese algo ${ }^{43}$.

No tiene sentido, pues, pensar en deberes u obligaciones que no están correlacionadas con algún derecho ${ }^{44}$ y ${ }^{45}$. Si ello es así, entonces, la pregunta a resolver es la siguiente: en términos constitucionales, iexiste el derecho, en sentido estricto, de los trabajadores de negociar colectivamente con sus empleadores?

Según lo señalado expresamente por la Norma Suprema, el Estado reconoce el derecho de negociación colectiva. iEsto quiere decir, entonces, que está claramente determinado el derecho de los trabajadores de negociar colectivamente con sus empleadores? En nuestra opinión, no basta con la literalidad del texto constitucional para afirmar la existencia del señalado derecho. Y es que, tal como resaltó el mismo Hohfeld ${ }^{46}$, los ordenamientos jurídicos normalmente utilizan a la ligera la expresión «derecho» para referirse a una amplia gama de conceptos jurídicos, tales como las nociones de «privilegio», «potestad», «inmunidad», etcétera.

En el mismo sentido se pronuncia Alexy ${ }^{47}$ quien, en lo que respecta específicamente a los derechos fundamentales (como la negociación colectiva), explica que con ese término en realidad se puede estar haciendo referencia a conceptos tan diversos como «derechos a algo», «libertades» $\mathrm{y}$ «competencias». Prueba del uso ambiguo de este término en el lenguaje jurídico lo encontramos en nuestra propia Carta Magna, que en su artículo 2 señala que toda persona tiene derecho, por ejemplo, a la libertad de conciencia y de religión (numeral 3), a las libertades de información, opinión y expresión (numeral 4), a la libertad de tránsito y de residencia (numeral 11), a la libertad de contratación (numeral 14), a la libertad de trabajo (numeral 15), etc.

43 Kelsen también sostiene la existencia dentro del derecho de esta relación diádica indisoluble entre «derecho» $y$ «deber». KeLSEN, Hans. Teoría pura del derecho. México D.F.: UNAM, 1979, p. 143.

44 HOHFELD, W. N. Conceptos jurídicos fundamentales. Genaro R. Carrión (trad.). Buenos Aires: Centro Editor de América Latina, 1968, pp. 47-49.

45 Ferrajoli, por el contrario, afirmará que en virtud del carácter dinámico del sistema jurídico (donde las normas se producen, no se deducen) es muy posible que existan "derechos" sin "deberes" correlativos. No obstante, reconocerá que cuando el ordenamiento jurídico sanciona un deber lo hace para garantizar precisamente un derecho. Y es que, para Ferrajoli, los deberes son «garantías primarias» que prevé el ordenamiento con el fin de asegurar la eficacia de un derecho. Es decir, admite que cuando existe positivamente hablando un deber, es porque previamente el derecho ha previsto un derecho. FerRAJOLI, Luigi. Derechos y garantías: la ley del más débil. Madrid: Trotta, 1999, p. 43.

46 lbíd., pp. 5-47.

47 AleXY, Robert. Ob. cit, pp. 185-186. 
De esta forma, bien podría suceder que donde la Constitución habla de «derecho», por su contenido, en realidad estemos ante una «libertad» o un «privilegio» (que, para Hohfeld, son conceptos asociados ${ }^{48}$ ).

Efectivamente, en términos analíticos, un derecho existe cuando el ordenamiento confiere a alguien una pretensión o, lo que es lo mismo, la posibilidad de exigirle algo a alguien —incluso, forzosamenteque correlativamente tendrá el deber de otorgar ese algo ${ }^{49}$. Así, pues, la expresión «X tiene derecho» carece totalmente de sentido si no se especifica a qué tiene derecho X (el objeto materia de la pretensión) y, sobre todo, quién es el sujeto obligado a proporcionárselo (a quién se dirige la pretensión). En ese sentido, cuando se habla de «derechos», en realidad se está pensando en un enunciado del tipo «X puede exigirle a $\mathrm{Y}$ que le otorgue $\mathrm{Z}$ » $y$, por ende, que «Y tiene el deber de dar $\mathrm{Z}$ a $\mathrm{X}$ ». Derechos y deberes, pues, son nociones complementarias ${ }^{50}$.

No sucede lo mismo cuando el derecho consagra un privilegio o una libertad. Y es que, en estos casos, se niega la existencia de un deber. Ello es así porque cuando el ordenamiento confiere a alguien una libertad o un privilegio, precisamente, lo que hace es asegurar a su titular la posibilidad de hacer o no hacer algo a su sola discreción. Es decir, no le otorga a nadie el derecho o la pretensión de exigirle que haga o no haga ese algo y, como tal, el titular de la libertad no tiene la obligación de hacer o no hacer ese algo. En ese sentido, el complemento o correlativo de una libertad es un «no-derecho», mientras que su negación u opuesto jurídico será precisamente la presencia de un «deber» ${ }^{51}$. Por esta razón, Alexy ${ }^{52}$ dirá que un derecho fundamental consiste, en realidad, en una libertad cuando el ordenamiento, con el título de derecho, le confiere a su titular un permiso o, lo que es lo mismo, la alternativa de decidir si hace u omite algo. Claramente, pues, la idea o noción de libertad presupone la ausencia de obligaciones y prohibiciones.

Y si ello es así, entonces, la pregunta a resolver es si la Constitución tan solo les otorga a trabajadores y empleadores el permiso de negociar colectivamente (una libertad) o, por el contrario, garantiza la pretensión de los primeros frente a los segundos de negociar colectivamente (un derecho). Si es lo primero, claramente no habrá sustento constitucional para la opción de la LRCT de imponer el deber patronal de negociar colectivamente: si los empleadores tienen un permiso jurídico para negociar (que incluye la posibilidad de decidir no hacerlo), entonces no tendrían el deber de negociar y, por tanto, los trabajadores con respecto a ellos tendrían un no-derecho a negociar (como se dijo en el punto

$48 \mathrm{O}$, en palabras de Hohfeld, correlativos. HOHFELD, W. N. Ob. cit., p. 56.

49 lbíd., p. 50.

50 lbíd., p. 49.

51 lbíd., pp. 50-67

52 Alexy, Robert. Ob. cit., pp. 214 -217, 222-224.

EL DEBER DE NEGOCIAR Y EL ARBITRAJE POTESTATIVO COMO PARTE DEL CONTENIDO DEL DERECHO CONSTITUCIONAL DE NEGOCIACIÓN COLECTIVA

OBLIGATION OF NEGOTIATION AND FACULTATIVE ARBITRATION AS PART OF CONSTITUTIONAL LAW CONTENT on COLLECTIVE NEGOTIATION 
precedente, en este marco, el deber de fomento y promoción no puede dar lugar a la obligación de negociar). En cambio, si fuera lo segundo, sí existiría un sólido argumento constitucional para afirmar la presencia del deber patronal de negociar colectivamente: si la Constitución consagra y protege la negociación colectiva como pretensión de los trabajadores frente a sus empleadores, entonces estos no podrían decidir no negociar (no tendrían a su favor el permiso de no negociar) y, por ende, tendrían el deber de sentarse a negociar (solo en este contexto, como veremos más adelante, el deber de fomento y promoción puede suponer el levantar las barreras que impiden que la negociación se lleve efectivamente a cabo).

\section{II.4 El permiso y la pretensión constitucional de negociar colectivamente.}

¿Es, pues, un permiso o una pretensión la negociación colectiva? Mayoritariamente la doctrina iuslaboralista se ha decantado por la opción de considerar a la negociación colectiva como una libertad (o un permiso). Por ejemplo, varios autores españoles, a pesar de la literalidad del artículo 37.1 de su Constitución ${ }^{53}$, sostienen que el derecho a la negociación colectiva, en verdad, consagra - entre otras - la libertad de los trabajadores y empresarios, frente a los poderes públicos, de decidir si negocian colectivamente o no, quedando excluido de su contenido normativo, como lógica consecuencia, la obligación del Estado de establecer el deber de las partes de negociar colectivamente ${ }^{54}$. En el mismo sentido se han pronunciado Gernigon, Odero y Guido, quienes sostendrán que «de los convenios de la OIT sobre negociación colectiva no se deriva la obligación formal de negociar» ${ }^{55} \mathrm{y}$, por tanto, que «dado que el carácter voluntario de la negociación colectiva es un aspecto

53 Dicho artículo textualmente señala lo siguiente: «la ley garantizará el derecho a la negociación colectiva laboral entre los representantes de los trabajadores y empresarios, así como la fuerza vinculante de los convenios colectivos".

54 Efectivamente, Lahera dirá que «la negociación colectiva es, en esencia, una libertad de negociar convenios colectivos, que no consciente interferencias impeditivas y obstaculizadoras de los poderes públicos». LAHERA FORTEZA, Jesús. Manual jurídico de negociación colectiva. Madrid: La Ley, 2008, p. 67) y, por tanto, «no se garantiza constitucionalmente un deber de negociar» (Ibíd., p. 82). Marrero, suscribiendo la misma opinión, dirá que «los artículos 28.1 y $37.1 \mathrm{CE}$ garantizan la libertad de negociación colectiva, entendida como la facultad de iniciar o no el trato contractual con la otra parte [...], por tanto, no se garantiza constitucionalmente un deber de negociar». MARRERO SÁNCHEZ, Estella María. «El derecho constitucional de negociación colectiva». Revista de Derecho Social, 59 (2012), p. 178. Finalmente, Sala Franco rotundamente sostendrá, en cuanto a la negociación colectiva, que «se trata de un simple derecho [...] que no implica un deber de negociar para la contraparte» (SALA FRANCO, Tomás. «El derecho constitucional a la negociación colectiva». En María Emilia CASAS BAamonde, Federico DuRÁn LóPEZ y Jesús CRuz Villalón [coords.]. Las transformaciones del derecho del trabajo en el marco de la Constitución española: estudios en homenaje al profesor Miguel Rodríguez-Piñero y Bravo-Ferrer. Madrid: La Ley, 2006, p. 323) porque "cuando los ordenamientos tradicionales reconocen el derecho a la negociación colectiva lo hacen normalmente frente al Estado, exigiendo de este un deber de respeto y de no intromisión en la misma, no reconociendo paralelamente un deber u obligación de negociar para la contraparte» (Ibíd., p. 324).

55 GERNIGON, Bernard, Alberto ODERO y Horacio GuIDO. «Principios de la OIT sobre la negociación colectiva». Revista Internacional del Trabajo, 119, 1 (2000), p. 45. 
fundamental de los principios de la libertad sindical, la negociación colectiva no puede ser impuesta a las partes ${ }^{56}$.

Para estos autores, claramente no hay lugar para el deber de negociar, al menos no en el marco de los pronunciamientos de la OIT. Así, pues, si trasladáramos irreflexivamente estas respetables opiniones a la dogmática constitucional peruana daría como resultado que se entienda a la negociación colectiva ahí consagrada como un simple permiso de negociar, y en esa medida la obligación patronal de negociar prevista en la LRCT resultaría inconstitucional.

En nuestra opinión, a diferencia de otros ordenamientos jurídicos (como el español), en el Perú sí se ha consagrado, en el artículo 28 de la Constitución, la pretensión de los trabajadores de negociar colectivamente con sus empleadores (lo que, como vimos, no es incompatible con el Convenio 98 de la OIT). Ello es así porque, primero, el permiso de negociar colectivamente ya está previsto en el artículo 2, numeral 14, de la propia Constitución (y sería claramente absurdo afirmar que los dos artículos consagran exactamente lo mismo) y, segundo, porque una concepción de la negoción colectiva como pretensión es lo que se desprende de una lectura atenta de los pronunciamientos del Tribunal Constitucional sobre esta materia.

Empecemos por lo primero. La Constitución en su artículo 2, numeral 14, dispone que «toda persona tiene derecho: [...] a contratar con fines lícitos». Como sería un contrasentido afirmar que dicha disposición consagra la pretensión de contratar (otra prueba del uso poco riguroso del término derecho), nuestro Tribunal Constitucional en reiterada jurisprudencia ha resaltado que aquella, en realidad, contiene las denominadas «libertad de contratación» $\mathrm{y}$ «libertad contractual»:

7. Este Tribunal ya ha tenido oportunidad de destacar que el derecho a la libre contratación, reconocido en los artículos 2, inciso 14), y 62 de la Constitución, se fundamenta en el principio de autonomía de la voluntad, el que, a su vez, tiene un doble contenido: «a. Libertad de contratar, también llamada libertad de conchusión, que es la facultad de decidir cómo, cuándo y con quién se contrata; y b. Libertad contractual —que forma parte de lasdenominadas libertades económicas que integran el régimen económico de la Constitución (Cf. STC 01405-2010-PA/TC, fundamento 12)-, también conocida como libertad de configuración interna, que es la facultad para decidir, de común acuerdo, el contenido del contrato [SSTC 00026-2008-PI/TC y 00028-2008-PI/TC (acumulados), fundamento 52; STC 2185-2002-AA/TC, fundamento 2]. Desde esta perspectiva, según este Tribunal, «el derecho a la libre contratación se concibe como el acuerdo o convención de voluntades entre dos o más

EL DEBER DE NEGOCIAR Y

EL ARBITRAJE POTESTATIVO COMO PARTE DEL CONTENIDO DEL DERECHO CONSTITUCIONAL DE NEGOCIACIÓN colectIVA

OBLIGATION OF NEGOTIATION AND FACULTATIVE ARBITRATION AS PART OF CONSTITUTIONAL LAW CONTENT on COLLECTIVE NEGOTIATION 
personas naturales y/o jurídicas para crear, regular, modificar o extinguir una relación jurídica de carácter patrimonial. Dicho vínculo - fruto de la concertación de voluntades—debe versar sobre bienes o intereses que posean apreciación económica, tengan fines lícitos y no contravengan las leyes de orden público» (STC 7339-2006-PA/TC, fundamento 47).

8. El contenido mínimo o esencial del derecho a la libre contratación, según ha señalado este Tribunal [STC 0004-2004-AI/TC, 0011-2004-AI/ TC, 0012-2004-AI/TC, 0013-2004-AI/TC, 0014-2004-AI/TC, 00152004-AI/TC, 0016-2004-AI/TC y 0027-2004-AI/TC (acumulados), fundamento 8], está constituido por las siguientes garantías:

- Autodeterminación para decidir la celebración de un contrato, así como la potestad de elegir al co celebrante.

- Autodeterminación para decidir, de común acuerdo [entiéndase: por común consentimiento], la materia objeto de regulación contractual $[\ldots]^{57}$.

Así, pues, en virtud de la libre contratación las personas jurídicas tienen permitido decidir la celebración de un contrato (o acuerdo de voluntades), elegir a la contraparte y fijar su contenido. Vale decir, más allá de los términos que se utilizan, en el artículo 2, numeral 14, de la Constitución se consagra el permiso de contratar. Y desde que las organizaciones sindicales son personas jurídicas (al igual que los empleadores) y el convenio colectivo es un acuerdo o convención de voluntades por la que se crean, regulan, modifican o extinguen derechos y obligaciones referidas a las remuneraciones, condiciones de trabajo, productividad y demás aspectos concernientes a las relaciones laborales ${ }^{58}$, no cabe duda de que dicha disposición constitucional consagra lo que hemos denominado como el permiso de negociar colectivamente.

¿Esto quiere decir, entonces, que las partes de la relación laboral son libres a los efectos de decidir si acuden (o no) a negociar colectivamente? En nuestra opinión, la respuesta sería afirmativa si es que no existiera también el artículo 28 de la Constitución que, por su parte, consagra la pretensión de negociar colectivamente de los trabajadores. En efecto, el propio Tribunal Constitucional, en su sentencia del 26 de marzo de 2003, recaída en el expediente 0261-2003-AA/TC, señaló lo siguiente:

[...], interesa poner de relieve que el artículo 28 de la Constitución debe interpretarse en el sentido de que, si bien esta labor de fomento y promoción de la negociación colectiva, implica, entre otras acciones,

57 STC del 20 de marzo de 2012, recaída en el expediente 02175-2011-PA/TC, párr. 7 y 8 (las cursivas y los resaltados son del original). En el mismo sentido, véase: (i) STC del 5 de diciembre de 2006, recaída en el expediente 1963-2006-PA/TC, párr. 16; (ii) STC del 20 de diciembre de 2005, recaída en el expediente 4788-2005-PA/TC, párr. 7; y (iii) STC del 11 de noviembre de 2003, recaída en el expediente 008-2003-Al/TC, párr. 26.

58 Cf. STC del 12 de agosto de 2005, recaída en el expediente 008-2005-PI/TC, párr. 29. 
que el Estado promueva las condiciones necesarias para que las partes negocien libremente, antes situaciones de diferenciación admisible, el Estado debe realizar determinadas acciones positivas para asegurar las posibilidades de desarrollo y efectividad de la negociación colectiva, pudiendo otorgar determinado «plus de tutela» cuando esta sea la única vía para hacer posible la negociación colectiva ${ }^{59}$.

Como se aprecia, el Tribunal Constitucional señala que el objetivo o la finalidad del deber de fomentar y promover la negociación colectiva es que esta, en los hechos, se vea efectivamente desarrollada o, lo que es lo mismo, que se realice realmente. Como explica Sanguineti ${ }^{60}$, «se reconoce, de esta forma, que la vigencia efectiva del principio de autonomía colectiva exige que el Estado organice el sistema de negociación colectiva atendiendo a criterios no solo de libertad sino, además, de posibilidad e iniciativa reales. Y que ello puede demandar, cuando existan motivos que los justifiquen, la adopción de medidas dirigidas a evitar que los procesos de negociación se trunquen o no puedan iniciarse».

Claramente, pues, el deber de fomento y promoción de la negociación colectiva exige al Estado adoptar todas las medidas necesarias para asegurar que aquella se materialice en los hechos y no solo que los sujetos colectivos puedan elegir libremente si se acogen o no a la negociación colectiva. Y si ello es así, entonces el mencionado Tribunal entiende que la Constitución ordena al Estado fomentar y proteger el ejercicio de una pretensión y no de un simple permiso o habilitación (si la negociación colectiva fuera esto último podría no producirse y claramente ese es una posibilidad que la Constitución quiere evitar). Solo así se explica que, en aplicación de dicho deber y en consideración a las particularidades del sector de la construcción civil (naturaleza eventual de las obras y alta rotación laboral), el Alto Tribunal haya fijado en la resolución antes citada la obligación de la parte empresarial de dicho sector de negociar colectivamente en el nivel de rama de actividad ${ }^{61}$.

El razonamiento que estaría detrás de ese fallo sería el siguiente: desde que a los trabajadores del sector de la construcción — como a cualquier otro colectivo de trabajadores - la Constitución les confiere la pretensión de negociar colectivamente, y esta no es viable en la empresa, entonces el Estado en cumplimiento de su deber de fomentar y promover la negociación colectiva tendrá que imponerle a los empleadores del sector el deber de negociar el pliego de reclamos correspondiente en el nivel de rama. A esto se reduce el denominado «plus de tutela»: a la necesidad

59 STC del 26 de marzo de 2003, recaída en el expediente 0261-2003-AA/TC, párr. 3 (las cursivas son nuestras)

60 SANGUINETI RAYMOND, Wilfredo. Ob. cit., p. 60.

61 Cf. STC del 26 de marzo de 2003, recaída en el expediente 0261-2003-AA/TC, párr. 3.3

EL DEBER DE

NEGOCIAR Y

EL ARBITRAJE

POTESTATIVO

COMO PARTE

DEL CONTENIDO

DEL DERECHO

CONSTITUCIONAL

DE NEGOCIACIÓN

COLECTIVA

OBLIGATION OF

NEGOTIATION

AND FACULTATIVE

ARBITRATION

AS PART OF

CONSTITUTIONAL

LAW CONTENT

on COLLECTIVE

NEGOTIATION 
de imponer el nivel supraempresarial de negociación, en desmedro de la voluntad de las partes (tal como lo exige la LRCT), con el fin de asegurar la pretensión de los trabajadores de negociar colectivamente (en el caso de los trabajadores de la construcción civil no bastaba con imponer el deber de negociar). Dicho de otra manera, porque los trabajadores tienen la pretensión de negociar colectivamente con sus empleadores, si las circunstancias así lo exigen, podrá imponerse no el deber permanente de negociar, sino la obligación excepcional de hacerlo en un nivel determinado.

Así pues, la pretensión de negociar, que debe fomentarse y promoverse, es anterior al «plus de tutela» y, comotal, no se deriva de este (por el contrario, en tanto existe la primera, por el segundo se puede excepcionalmente llegar a imponer el nivel supraempresarial de negociación). No cabe duda, entonces, que en la sentencia bajo comentario el Tribunal manejó una concepción de la negociación colectiva como un derecho en sentido estricto; concepción que ha sido reafirmada en sus pronunciamientos más recientes, a pesar de su aparente contradicción.

Efectivamente, en su sentencia del 17 de agosto de 2009, recaída en el expediente03561-2009-PA/TC, el Tribunal Constitucional recogió el principio de negociación libre y voluntaria en los términos que ha sido planteado por el Comité de Libertad Sindical:

12. El principio de negociación libre y voluntaria se encuentra reconocido en el artículo 4 del Convenio núm. 98, según el cual para que la negociación colectiva sea eficaz, debe tener carácter voluntario y no estar mediado por medidas de coacción que alterarían el carácter voluntario de la negociación. [...].

13. De este modo, en virtud de este principio, el Estado no puede ni debe imponer, coercitivamente, un sistema de negociaciones colectivas a una organización determinada, intervención estatal que claramente atentaría no sólo contra el principio de la negociación libre y voluntaria, sino también contra los derechos de libertad sindical y de negociación colectiva. [...].

En buena cuenta, el principio de la negociación libre y voluntaria incluye: a) la libertad para negociar, entendida como la libertad de elegir entre acudir o no a negociar con una o con otra organización sindical $[\ldots]$.

Por dicha razón, puede concluirse que los convenios de la OIT sobre negociación colectiva no imponen la obligación formal de negociar [...], ni obligan a los Estados a imponer coercitivamente la negociación colectiva $[\ldots]^{62}$. 
No obstante, en la misma ejecutoria el Tribunal señaló que la negativa patronal de negociar con los representantes de los trabajadores constituye una vulneración de la negociación colectiva:

21. [...] el ejercicio de la negociación colectiva no se limita sólo a la presentación de los pliegos de peticiones y a la celebración de convenciones colectivas, sino que incluye [...] la garantía de que los representantes de unos y otros sean oídos y atendidos.

22. Por dicha razón, este Tribunal considera pertinente establecer, de manera enunciativa, algunos supuestos en los que puede considerarse afectado el derecho de negociación colectiva. Así, este derecho se vulnera cuando:

[...].

b. El empleador se niega a recibir a los representantes de los trabajadores o a negociar con ellos en los plazos y condiciones que establece la ley. $[\ldots]^{63}$.

Así, pues, en la sentencia señalada, al mismo tiempo que se proclamó la libertad de la parte empresarial para decidir entre negociar o no (lo que presupone manejar una concepción de la negociación colectiva como permiso), se precisó que la negativa empresarial a negociar con los representantes de los trabajadores supone una violación de su derecho a la negociación colectiva (lo que implica manejar una concepción de la misma como pretensión). Aun cuando podría sostenerse que el deber de negociar con la comisión negociadora designada por los trabajadores, no afecta necesariamente el principio de negociación libre y voluntaria (operarían en momentos distintos) y, por tanto, que el máximo intérprete de la Constitución maneja una concepción de la negociación colectiva como permiso. A nuestro juicio, en este pronunciamiento se confirma el carácter de pretensión de la negociación colectiva, desde que al momento de resolver el fondo de la controversia claramente dispuso lo siguiente:

23. [...], este Tribunal concluye que las Asociaciones emplazadas han abusado de su libertad para negociar, pues, actuando de mala fe, han inasistido injustificadamente a la gran mayoría de reuniones convocadas por la División para negociar el pliego de reclamos presentado por el Sindicato demandante.

24. Asimismo, las Asociaciones emplazadas han abusado de su libertad para decidir el nivel de la negociación, pues a pesar de que el Sindicato demandante ha solicitado que la negociación se desarrolle por rama de actividad, las Asociaciones emplazadas se han negado a negociar con él,

EL DEBER DE NEGOCIAR Y

EL ARBITRAJE POTESTATIVO COMO PARTE DEL CONTENIDO DEL DERECHO CONSTITUCIONAL DE NEGOCIACIÓN COLECTIVA

OBLIGATION OF NEGOTIATION AND FACULTATIVE ARBITRATION

AS PART OF CONSTITUTIONAL LAW CONTENT on COLLECTIVE NEGOTIATION 
y además han tenido conductas que han dificultado o hecho imposible la negociación colectiva.

25. Por estas razones, este Tribunal considera que las Asociaciones emplazadashan vulnerado el derecho de negociación colectiva del Sindicato demandante, toda vez que han abusado de sus libertades para negociar y para decidir el nivel de la negociación, $[\ldots]^{64}$.

Como se puede apreciar, para el Alto Tribunal la inasistencia injustificada a las reuniones convocadas para negociar el pliego - y, sobre todo, la negativa patronal a negociar el nivel de la negociación, en tanto dificultaron o hicieron imposible el desarrollo de la negociación colectiva - supusieron la transgresión del derecho de los trabajadores portuarios a negociar colectivamente. Contrario sensu, no cabe duda de que la norma constitucional que consagra la negociación colectiva impone a los empleadores el deber de negociar el nivel de la negociación e, incluso, el contenido del pliego, desde que se exige que la negociación colectiva sea posible de realizar.

Si ello es así, más allá de lo dicho sobre el principio de negociación libre y voluntaria, lo cierto es que el Tribunal en esta resolución también maneja una concepción de la negociación colectiva como pretensión: sólo así se explica por qué, en este caso, también se resaltó la obligación patronal de negociar con los trabajadores (recuérdese: este deber solamente existe si previamente existe el derecho o la pretensión de negociar colectivamente). Se confirma, entonces, el carácter de derecho en sentido estricto de la negociación colectiva.

\section{III.NEGOCIACIÓN DE BUENA FE Y ARBITRAJE POTESTATIVO: ¿ARBITRAJE VOLUNTARIO O POTESTATIVO?}

El reglamento de la LRCT, aprobado por decreto supremo 011-92-TR (en adelante el Reglamento), sufrió una modificación (o tal vez precisión) en el año 2011, de cara a instituir el arbitraje potestativo en determinadas circunstancias ante el fracaso de la negoción directa. Son dos las normas que se dieron en ese sentido: el decreto supremo 014-2011-TR y la resolución ministerial 284-2011-TR. Desde la entrada en vigor de la LRCT en el año 1992 se discutió la naturaleza voluntaria o potestativa del arbitraje y las posturas de los sujetos laborales sobre el particular estuvieron claramente definidas desde el principio: para los empleadores el arbitraje era necesariamente voluntario, mientras que los trabajadores lo concebían como potestativo. Por su parte, la Autoridad Administrativa de Trabajo (AAT) apostó inicialmente por un arbitraje

64 STC del 17 de agosto de 2009, recaída en el expediente 03561-2009-PA/TC, párr. 23-25 (las cursivas son nuestras). 
de carácter potestativo ${ }^{65}$, pero esta postura tuvo muy corta duración pues al poco tiempo dio un giro en favor del arbitraje voluntario ${ }^{66}$, posición que ha mantenido hasta la fecha y que, con carácter general, no se entendería superada por la aludida reforma normativa.

En efecto, el artículo 61-A que se ha introducido en el Reglamento establece los supuestos en los que se faculta a las partes a interponer el arbitraje facultativo en el marco de una negociación colectiva, lo que hace pensar que, salvo en esos casos, el arbitraje no sería potestativo sino voluntario. Los supuestos señalados en la indicada norma son dos: (i) cuando las partes, en la primera negociación, no se pongan de acuerdo en la determinación del nivel o no arriben a un convenio colectivo, y (ii) si en el proceso de negociación del pliego de peticiones se advierten actos de mala fe que tengan por objeto dilatar, entorpecer o evitar el logro de un acuerdo.

¿Pero cuál es la naturaleza del arbitraje como medio alternativo de controversias laborales? Para la OIT, siguiendo la pauta de una negociación libre y voluntaria, el arbitraje debería gozar de similar consideración, es decir, la opción por el arbitraje debería seguir también la ruta de la voluntariedad, tal como señala la recomendación 92 de la OIT de 1951, sobre la conciliación y el arbitraje voluntarios ${ }^{67}$.

No obstante, en el ámbito de las relaciones laborales es posible identificar, esencialmente, según su exigibilidad, tres clases de arbitraje: voluntario, obligatorio y unilateral. El arbitraje voluntario es aquel en que las partes deciden, de común acuerdo, someter la controversia a un tercero designado por ellas mismas. El arbitraje obligatorio, por su parte, es aquel impuesto a las partes por el Estado, debiendo aquellas acudir necesariamente a un tercero para la solución del conflicto. Finalmente, el arbitraje unilateral (también conocido como potestativo o voluntario vinculante) es aquel por el cual una disposición (heterónoma o autónoma) faculta a una de las partes la posibilidad de someter el conflicto a un tercero, quedando obligada la otra parte a dicho sometimiento.

Se suele confundir el arbitraje unilateral o potestativo con el obligatorio, porque no existe el consenso de las partes, sino únicamente la decisión (vinculante) de una de ellas al momento de someter la controversia a un tercero. Pero la diferencia sustancial consiste en que el arbitraje

65 Pueden verse las resoluciones del 14 de junio de 1994 y 5 de setiembre de 1994 recaídas en los expedientes 751-93 (Papeleras Especiales S.A.) y 983-93 (Editora Perú S.A.), respectivamente.

66 Véase la resolución del 6 de febrero de 1995, recaída en el expediente 414-94 (Avícola Esquivel S.A.).

$67 \mathrm{El}$ artículo 6 de la Recomendación 92 establece lo siguiente: «6. Si un conflicto ha sido sometido al arbitraje, con el consentimiento de todas las partes interesadas, para su solución final, debería estimularse a las partes para que se abstengan de recurrir a huelgas y a lockouts mientras dure el procedimiento de arbitraje y para que acepten el laudo arbitral» (el énfasis es nuestro).

EL DEBER DE NEGOCIAR Y

EL ARBITRAJE POTESTATIVO COMO PARTE DEL CONTENIDO DEL DERECHO CONSTITUCIONAL DE NEGOCIACIÓN COLECTIVA

OBLIGATION OF NEGOTIATION AND FACULTATIVE ARBITRATION AS PART OF CONSTITUTIONAL LAW CONTENT on COLLECTIVE NEGOTIATION 
obligatorio es impuesto indefectiblemente a las partes cuando el conflicto no ha sido resuelto por ellas mismas, mientras que en el arbitraje unilateral o potestativo no hay una imposición automática, porque siempre queda la posibilidad de que la parte facultada para someter el conflicto a un tercero no lo haga. ¿Es este último tipo de arbitraje el que ha sido recogido por la LRCT? Consideramos que sí, y es más, creemos que se trata de una posición con claro sustento constitucional. Veamos.

Como hemos advertido anteriormente, el artículo 28.2 de la Constitución reconoce a los trabajadores el derecho de negociación colectiva, proclamando su fomento y la promoción de formas de solución pacífica de los conflictos laborales. Se está refiriendo a los medios alternativos de solución de conflictos, tanto autónomos o de negociación asistida (conciliación y mediación) como heterónomos (arbitraje) ${ }^{68}$. ¿Pero qué supone en estricto que el Estado deba promover formas de solución pacífica de los conflictos laborales?

Desde nuestro punto de vista, en el contexto del artículo 28.2, referido a la negociación colectiva, y dentro de un alcance más general de todo el artículo 28, esto supone una apuesta clara y contundente por la necesidad de componer el conflicto antes que de dejarlo abierto, pero supone también considerar la posibilidad de acudir a la huelga, en tanto medio de fuerza o expresión abierta del conflicto, como una última ratio. Como afirma Blancas ${ }^{69}$, el fundamento «de este mandato constitucional reside en el rechazo del Estado a la prolongación indefinida de los conflictos laborales». Por eso, para este autor, el arbitraje potestativo es:

[...] una fórmula adecuada al campo de las relaciones laborales, porque si ha de depender de la voluntad del empleador aceptar o no el arbitraje, la posibilidad de dar solución al conflicto queda en sus manos, es decir, subordinada a sus intereses, por lo que en el caso de negarse a aceptar el arbitraje el conflicto permanecerá abierto y, muy probablemente, la consecuencia de ello será obligar a los trabajadores y sus organizaciones a adoptar medidas de presión o de fuerza ${ }^{70}$.

Se impone entonces en este contexto al Estado un mandato claro y clave de promover mecanismos que permitan establecer una solución definitiva

68 Como precisa Blancas: «Por su ubicación sistemática, debemos asumir que la expresión conflictos laborales, está referida a los conflictos colectivos y, dentro de estos, a los de intereses o económicos, porque tanto los conflictos individuales como los conflictos colectivos de aplicación son de índole jurídica y, por consiguiente, cuentan con cauces jurisdiccionales específicamente establecidos para su solución». (Blancas Bustamante. Ob. cit., p. 447).

69 lbíd., p. 450.

70 Para Pasco: «La apertura a un sistema puramente voluntarista tiene el inconveniente de que la parte más fuerte puede frustrar el arbitraje con su sola abstención. Si dicha parte es el empleador, como suele suceder, los trabajadores se ven enfrentados a una disyuntiva penosa: la huelga o la frustración total de sus expectativas. Y si su propia flaqueza les impide recurrir a la vía directa, el patrono terminará imponiendo las reglas de juego" (citado por BLANCAS BUSTAMANTE. Ob. cit., p. 451). En términos parecidos se pronuncia MORALES CORRALES, Pedro. «Problemas del arbitraje en la negociación colectiva». Derecho \& Sociedad, 30 (2000), p. 134. Lima. 
del conflicto colectivo. De opinión similar es Gorelli ${ }^{71}$ —refiriéndose a la LRCT_- cuando afirma que la regulación peruana «parece pretender evitar que se acuda a medios de solución directos o agresivos, como la huelga, ante la falta de acuerdo durante la negociación colectiva». Esto no significa, por cierto, desconocer el reconocimiento del derecho de huelga como un derecho fundamental de los trabajadores. Estos serán siempre los llamados a decidir, en cada oportunidad y con arreglo a ley, si declaran la huelga u optan por el arbitraje. En este último caso, la decisión adoptada por los trabajadores debería vincular a la contraparte empresarial ${ }^{72}$.

Un análisis sistemático de diversos preceptos de la normativa infraconstitucional apunta en esta dirección. En primer lugar, la LRCT señala en su artículo 61 que ante el fracaso de la negociación directa, «podrán las partes someter el diferendo a arbitraje». Este dispositivo legal se complementa con el primer párrafo del artículo 46 del Reglamento, que establece que, al término de la negociación directa o de la conciliación, de ser el caso, «cualquiera de las partes podrá someter la decisión del diferendo a arbitraje, salvo que los trabajadores opten por ejercer alternativamente el derecho de huelga». Esta última precisión resulta lógica, pues no sería admisible que la opción del empleador por el arbitraje termine vinculando a los trabajadores cuando estos decidan ir a la huelga, ya que ello equivaldría a vaciar de contenido el indicado derecho constitucional.

Finalmente, no puede dejar de mencionarse lo señalado por el artículo 63 de la LRCT, según el cual en caso que los trabajadores hubiesen optado por ejercer el derecho de huelga, para someter el diferendo a arbitraje se requerirá la aceptación del empleador, la que podrá ser expresa o tácita. No cabe dudadeque en este último caso nos encontramos ante un arbitraje voluntario, pero es precisamente lo establecido en este precepto, contrastado con el artículo 61 antes citado, lo que permite afirmar que, como regla, la LRCT y su reglamento consagran un arbitraje potestativo, pues en caso contrario carecería de sentido establecer la misma figura jurídica (arbitraje voluntario) en dos artículos, a pesar de que actúen en dos momentos diferentes, o más propiamente, «esta última precisión

71 GorelLI HERnÁNDEZ, Juan. «Procedimientos de solución extrajudicial de conflictos colectivos». En Autores Varios, José Luis Monereo (dir.). Los derechos de libertad sindical y de negociación colectiva en una perspectiva comparada. Granada: Comares, 2011, p. 243.

72 Para, si bien el arbitraje - a partir de su función primigenia de componedora de un conflicto- podría verse como un límite del derecho de huelga y, en esa medida, su uso debería ser restringido, merece la pena rescatar del mismo una función «más decisiva y valiosa», complementaria y fortalecedora de la negociación colectiva. Señala el citado autor que, en «un escenario donde los trabajadores pueden arrastrar a los empleadores a un arbitraje, las partes al momento de iniciar la negociación tendrán mayores incentivos para obrar de buena fe, dar propuestas serias y no entorpecer la negociación». UGAZ OlIVARES, Mauro. «La heterocomposición de las negociaciones colectivas de trabajo: el arbitraje potestativo". En V Congreso Nacional de la SPDTSS, Tendencias y perspectivas laborales: juicios, relaciones sindicales y marco interdisciplinario. Lima: SPDTSS, 2012, p. 277. 
solo tiene sentido si se interpreta que el arbitraje regulado por el artículo $61[\ldots]$ no requiere de dicha aceptación» ${ }^{73}$.

Esta es la postura, a nuestro parecer, que indubitablemente ha sido asumida por el Tribunal Constitucional, a partir de un análisis de los medios alternativos de solución de conflictos colectivos como preferentes al ejercicio del derecho de huelga, cuando esta fuese la opción de los trabajadores, resultando vinculante dicha decisión para la parte empresarial. Ya en la sentencia del 12 de agosto de 2005, recaída en el expediente 008-2005-PI/TC, el Alto Tribunal había establecido como justificación del mandato dirigido al Estado ex artículo 28.2 de la Constitución, de un lado, la consolidación de la paz laboral y el normal desarrollo de la actividad económica, lo cual no es posible asegurar si el desacuerdo de las partes se prolonga indefinidamente en el tiempo; y del otro, la necesidad de otorgar a ambas partes, por la vía pacífica, una adecuada satisfacción a sus pretensiones en conflicto ${ }^{74}$.

Posteriormente, en la resolución del Tribunal Constitucional aclaratoria de la sentencia de fecha 17 de agosto de 2009, recaída en el expediente 03561-2009-PA/TC, se señala que el reconocimiento del derecho de huelga en el artículo 28 de la Constitución, «en modo alguno implica el deber de promoverla», por el contrario, recuerda el Tribunal Constitucional, el mandato constitucional es por la promoción de las formas de solución pacífica de los conflictos laborales. Por tanto:

[...] si conforme a la voluntad del Constituyente, el derecho a la huelga debe ser reconocido (y en esa medida, respetado y garantizado), pero no promovido o fomentado, mientras sí deben ser promovidas las formas de solución pacífica de los conflictos laborales, resulta evidente que el arbitraje al que hace alusión el artículo 61 del decreto supremo 010-2003-TR, y que es el llamado a determinar el nivel de negociación ante la falta de acuerdo, es potestativo, y no voluntario. Es decir, ante la falta de acuerdo, y manifestada la voluntad de una de las partes de acudir al arbitraje, la otra tiene la obligación de aceptar esta fórmula de solución del conflicto.

Ello salvo, como ya se ha señalado, cuando los trabajadores opten por ejercitar su derecho de huelga. Finaliza el Tribunal señalando que una interpretación contraria a la expuesta:

[...] llevaría a la inconstitucional conclusión de que en caso de que los trabajadores optaran por acudir al arbitraje, el empleador tendría plena capacidad, con su negativa, de frustrar esta vía heterocompositiva de solución, obligando a los trabajadores a acudir a la huelga. Como es

73 Resolución del TC del 10 de junio de 2010, aclaratoria de la STC del 17 de agosto de 2009, recaídas en el expediente 03561-2009-PA/TC.

74 Cf. STC del 12 de agosto de 2005, recaída en el expediente 008-2005-PI/TC (fj. 35). 
evidente, ello no solo se opondría al deber del Estado de promover y fomentar formas pacíficas de solución del conflicto, sino que además haría de la huelga no un derecho fundamental libremente ejercido por el trabajador, sino una vía obligatoria impuesta indirectamente por el empleador, vaciando de contenido a este derecho fundamenta ${ }^{75}$.

En conclusión, el fundamento normativo del arbitraje potestativo como medio alternativo de solución de conflictos colectivos de trabajo lo encontramos en el artículo 28.2 de la Constitución. En ese sentido, las interpretaciones que entienden que tanto la LRCT como su reglamento recogen el arbitraje unilateral o potestativo tienen pleno fundamento constitucional, o para decirlo en otros términos, ni el reglamento es ilegal, ni este ni la LRCT resultan inconstitucionales por establecer un arbitraje de dicha naturaleza. Por el contrario, lo que termina siendo controvertido es que el arbitraje potestativo se circunscriba únicamente a los supuestos de determinación del nivel de negociación o a las negociaciones realizadas en contravención al principio de buena fe, porque a la luz de lo expresado en el presente trabajo resulta inconsistente considerar al arbitraje potestativo como una figura excepcional.

Recibido: 31/07/2013 Aprobado: 15/08/2013

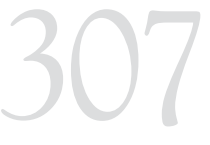

EL DEBER DE NEGOCIAR Y

EL ARBITRAJE POTESTATIVO COMO PARTE DEL CONTENIDO DEL DERECHO CONSTITUCIONAL DE NEGOCIACIÓN COLECTIVA

OBLIGATION OF NEGOTIATION AND FACULTATIVE ARBITRATION AS PART OF CONSTITUTIONAL LAW CONTENT ON COLLECTIVE NEGOTIATION 